\title{
OUR OLD BUILDINGS CAN BE SAFE IN EARTHQUAKE
}

\author{
Ian C. Smith*
}

\begin{abstract}
Demolition and redevelopment, or strengthening of earthquake risk buildings to current requirements is often uneconomic. A rational approach to strengthening is required which takes account of the extent and cost of strengthening, the desired economic building life, the owner's interests and the occupants safety. Strengthening costs for several recent projects are presented.
\end{abstract}

There has been much talk recently in Wellington about earthquake risk buildings and about the difficulties the city here has in bringing about a recognition of these risks and then the strengthening or replacement of the buildings involved.

Economic forces which have worked in the past to bring about natural redevelopment no longer apply and indeed a sort of stalemate now applies. On the one hand the City Council have notified owners of a large number of buildings of the potential hazards in their buildings and have requested that action be taken. On the other hand the owners, upon receipt of these notices, cower somewhat stunned - they look down the barrel of the crippling development costs or face some rearguard action to hold on to what they have for a little longer. The work of redevelopment is often beyond the means of the individual owner and it is left to developers and bigger lending institutions to make the bolder moves involved in full redevelopment. Note: in economic terms only a selected few sites warrant new building.

At the same time that commercial buildings are receiving attention there is agitation for retention of historic buildings, and buildings with aesthetic merit. These buildings can be saved and costs need not be prohibitive.

It is my contention that we can indeed take a midale road for commercial buildings which will both protect an individual owner's interests and at the same time prove equitable and viable as a proposition. Likewise there is a sensible and prudent line of approach to historic buildings. Let us first of all examine the background. There was an appreciation certainly in Wellington as early as 1848 and 1855 that earthquakes were destructive. Committee reports prepared at that time following the bad earthquakes then recorded the observations on the more effective building designs in earthquake. It was noted that timber buildings performed well and for a time this material was the recommended one for earthquake construction. Timber was good in earthquake and we see the result even today of the proliferation of such buildings at the time, in the evidence in those which still survive. Subsequently when it was learnt that timber buildings were dangerous

* Principal Ian C. Smith Consultants, The Terrace, Wellington. in fire there was a swing back toward masonry. This swing coincided with a lapse in memory of the earlier settlers partly influenced by the infiltration of European thoughts from new settlers. Buildings constructed in the late 19th century and the early part of this century are largely of a masonry type and it is these buildings which we see in our main business area today. Generally these commercial buildings built prior to 1930 are not reinforced and are not designed for earthquake. They are designed only to withstand wind forces in a static fashion much like a retaining wall resists the static forces due to earth pressure. Subsequent to the Napier earthquake in 1931 however building codes began to introduce earthquake requirements. At first it was only necessary to tie the various components together satisfactorily - later however equivalent lateral loads (like large wind forces) were imposed up to approximately one tenth of the weight of the building materials. Progressively more and more sophisticated requirements have been built into the building ordinances until today earthquake design of new buildings is very onerous indeed and the cost involved accounts for a very significant proportion of overall building cost.

Sadly this increasing sophistication has not necessarily meant an equivalent increase in safety. A law of diminishing returns applies. The degree of safety is increased in a large jump by the first steps in earthquake design - the tying together but less and less is gained with each new step in sophistication until the point is reached when some of the modern refinements must now be suspect in the light of real cost benefit - but that is another story. As it applies to older buildings there is real argument for a simpler approach to the earthquake provisions.

As a result of the events we are left today with a heritage of existing buildings which range from the modern, fully earthquake designed buildings to the older, 70-year old buildings, with virtually no earthquake design provisions. Such buildings of the latter type in many cases owe their lateral load features and hence possibly their survival to perhaps a luck in design or possibly foresight on the part of the individual Architect or builder involved.

It is this mixture of old and new buildings which are currently the subject of Council 
notifications and which therefore should be strengthened or replaced. And with historic buildings the remnants after an already extensive vetting process.

The questions are:

- What should we strengthen?

- How should we strengthen?

- What are the costs?

- What standard of design should be provided?

- What economic life should be allowed?

What Should we Strengthen

A building may be considered for strengthening if the following conditions are generally met.

(1) The overall fabric of the building should be in good condition and preferably well maintained.

(2) A Logical method of strengthening should be possible within the capacity of existing principal components and foundations.

(3) The cost of strengthening should not be more than about $30 \%$ of the cost of a replacement building.

(4) A life extension of 20 to 30 years should be planned.

(5) Reasonable replanning arrangements to suit modern needs should be included.

In addition when the building has an historic appeal and warrants preservation a greater cost up to say $10 \%$ more than the cost of a new building of the same floor area - might well be considered.

\section{How Should we Strengthen} are:

There are a number of approaches. These

(1) Removal of hazards such as chimneys, gables, long walls, and unsafe high storeys.

(2) Install simple steel bracing or ties to elements.

(3) Reduce the scale possibly by part demolition of upper storeys or by some other reduction in load.

(4) Upgrade the existing structure especially in the case of steel framed buildings. Provide new steel props as an independent floor support system in the case of concrete floored buildings. Prestress existing masonry walls to give them a tensile capacity.

(5) Provide new internal concrete walls to act as earthquake resisting elements.

(6) Amalgamate existing adjacent buildings by tying them together and thereby averaging their strength.
(7) Build new additions in concrete or steel construction and tie these to the adjacent existing buildings. Cost of the new building is offset by the increased building area and the consequent rent returns thereon and in the rejuvenation of the old buildings for an extended economic life.

(8) Provide new concrete sprayed skin walls over the existing masonry to give to that construction an earthquake strength.

(9) External corsetting by new reinforced concrete frame.

(10) Demolish and gut the interior and build a new structure inside the existing skeleton.

\section{What are the costs?}

The costs need not be so high, especially in the light of the present cost of new buildings. Typically an existing building can be strengthened and renovated for a 20-30 year economic life at a cost of about one-third of the cost of a new building. It follows that if a rent review nets an increase at least one-third the amount for a new building the renovation is viable. Sample costs for some recent projects are given in Table 1.

\section{What Standard of Design?}

There are no codes presently available for the strengthening or renovation of existing buildings. The Wellington City Council does however suggest that an overall earthquake provision equal to twothirds of the loading requirements for a new building be provided. Design details are left to the individual engineer or designer and it is not appropriate that other features such as ductility be provided to ensure much of an over-capacity. It is submitted however that this approach is viable for only an intermediate life extension such as 2030 years. Otherwise a more sophisticated approach is warranted. 
TABLE 1: SAMPLE STRENGTHENING COSTS

\begin{tabular}{|c|c|c|c|c|c|c|c|}
\hline $\begin{array}{l}\text { Building } \\
\text { Type }\end{array}$ & $\begin{array}{r}\text { No. of } \\
\text { Storeys }\end{array}$ & $\begin{array}{l}\text { Floor } \\
\text { Area }\end{array}$ & $\begin{array}{l}\text { Total } \\
\text { Contract }\end{array}$ & $\begin{array}{l}\text { Cost } \\
\text { Sq.M. }\end{array}$ & $\begin{array}{l}\text { Structural } \\
\text { Content }\end{array}$ & $\begin{array}{l}\text { Cost } \\
\text { Sq.M. }\end{array}$ & Remarks \\
\hline Commercial & 2 & 536 & 138,000 & 257 & 75,000 & 141 & $\begin{array}{l}\text { Partial renovation } \\
\text { to } 67 \% \text { code }\end{array}$ \\
\hline Office & 3 & 540 & - & - & 145,000 & 270 & Complete retrofit \\
\hline Office & 4 & 2,300 & 687,000 & 298 & - & - & $\begin{array}{l}\text { Reinstatement after } \\
30 \% \text { fire loss }\end{array}$ \\
\hline Retail & 2 & 2,500 & 200,000 & 80 & - & - & $\begin{array}{l}\text { Partial renovation } \\
\text { to } 67 \% \text { code }\end{array}$ \\
\hline University & 4 & 6,010 & $3,910,000$ & 647 & - & - & Complete retrofit \\
\hline $\begin{array}{l}\text { Reception to } \\
\text { Auditorium }\end{array}$ & - & 1,300 & 129,000 & 99 & - & - & $\begin{array}{l}\text { Renovation to full } \\
\text { code level }\end{array}$ \\
\hline Auditorium & $12 / 3$ & 1,580 & 222,000 & 140 & - & - & $\begin{array}{l}\text { Renovation to full } \\
\text { code level }\end{array}$ \\
\hline $\begin{array}{l}\text { Office and } \\
\text { Retail }\end{array}$ & & 15,330 & $1,250,000$ & 82 & - & - & $\begin{array}{l}\text { Renovation to } 80 \% \\
\text { code }\end{array}$ \\
\hline
\end{tabular}

